\title{
IMMUNOMODULATORY EFFECTS OF ETHANOL EXTRACT OF CURCUMA MANGGA RHIZOMES IN MICE
}

\author{
YUANDANI*, EDY SUWARSO
}

Department of Pharmacology, Faculty of Pharmacy, Universitas Sumatera Utara, 5 Jalan Almamater, USU-Kampus, Medan 20155, Indonesia. Email: yuan_dani@yahoo.com

Received: 10 March 2017, Revised and Accepted: 24 May 2017

\section{ABSTRACT}

Objective: This study was conducted to evaluate the immunomodulatory effects of ethanol extract of Curcuma mangga by in vivo study.

Methods: The ethanol extract of $C$. mangga was comprised to carbon clearance method for its immunomodulatory potential. The extract was administered orally at doses of 100, 200, and $400 \mathrm{mg} / \mathrm{kg}$ BW to mice for 7 days. On day 8 , carbon ink was injected, and the blood was collected for measurement of elimination of carbon. Total leukocyte count was also determined.

Results: The evaluation of immunomodulatory potential of ethanol extract of $C$. mangga revealed a dose-dependent increase in phagocytosis ability. The phagocytic index of ethanol extract of $C$. mangga was more than those of negative control, indicating the immunostimulatory activity of $C$. mangga. It showed low stimulation on total leukocyte count.

Conclusion: The results indicate that ethanol extract of $C$. mangga rhizomes possesses immunomodulatory activity and has therapeutic potential for the treatment of infectious diseases.

Keywords: Curcuma mangga, Phagocytosis, Total leukocyte count, Immunomodulatory.

(C) 2017 The Authors. Published by Innovare Academic Sciences Pvt Ltd. This is an open access article under the CC BY license (http://creativecommons. org/licenses/by/4. 0/) DOI: http://dx.doi.org/10.22159/ajpcr.2017.v10i9.18398

\section{INTRODUCTION}

Immune system is a complex system, but its components are interrelated act in a highly coordinated and specific manner. Thus, most infections caused by pathogens in most individuals are short-lived with minor permanent damage. Innate immunity is the most universal and the most rapidly acting, which is largely mediated by professional immunocytes (neutrophils, monocytes, and macrophage cells) [1]. Phagocytosis is an effective innate internal defense and in activating the adaptive immune response. At the site of infection, phagocytes engulf and destroy the foreign substances by microbicidal agents [2]. There are various toxic molecules for microorganisms generate from superoxide anion $\left(\mathrm{O}_{2}^{-}\right)$such as hypochlorous acid $\left(\mathrm{HOCl}^{-}\right)$, hydroxyl radicals $\left(\mathrm{OH}^{-}\right)$, and singlet oxygen. In addition, nitric oxide ( $\left.\mathrm{NO}^{-}\right)$which is produced by macrophages during the respiratory burst reacts with $\mathrm{O}_{2}$ - to form peroxynitrite, a strong antimicrobial $[3,4]$.

Several plant extracts and their isolates have been reported for their immunomodulatory activity [5-7]. The extracts of many herbs such as Panax ginseng, Tinospora cordifolia, Phyllanthus amarus, Centella asiatica, Trigonella foenum graecum, Pouteria cambodiana, Picrorhiza scrophulariiflora, Garcinia mangostana, Thymus guyonii, Salvia verbenaca, Capparis spinosa, and Stachys circinata were able to upregulate or downregulate both innate and adaptive arms of the immune response [8-11].

The plants belonging to the genus Curcuma (family: Zingiberaceae) are widely distributed in most tropical countries [12]. Among them, Curcuma mangga is widely used in traditional medicine to treat various diseases such as stomach disorders, fever, and cancer-related diseases [13]. The variety of its organic compound of medicinal importance such as $\beta$-sitosterol, curcumin, demethoxycurcumin, and bisdemethoxycurcumin has emphasized to evaluate its immunomodulatory activity [13,14]. The extracts and compounds isolated from C. mangga have revealed a wide spectrum of pharmacological activities, including analgesic, anti-inflammatory, antioxidant, anticancer, antifungal, and nitric oxide inhibitory activities [15-18]. In addition, the ethanol extract of $C$. mangga did not induce significant short-term toxicity as reported in our previous study [19]. However, there are little studies to validate the traditional use of $C$. mangga leaves to treat diseases related to the immune system

Previous in vitro study has indicated that the methanol extracts of $C$. mangga displayed strong immunomodulatory effects on polymorphonuclear neutrophils and macrophage cells. However, in vivo study is necessary to elaborate its immunomodulatory activity. This study was conducted to investigate the effects of ethanol extract of $C$. mangga on phagocytosis ability of mice leukocytes as well as total leukocyte count

\section{METHODS}

\section{Chemicals and reagents}

The chemicals used in this study were ethanol (Smart Lab, Indonesia) and natrium carboxymethylcellulose (Na-carboxymethylcellulose [CMC]) (Sigma, USA), imboost ${ }^{\circledR}$ (Soho, Indonesia), China ink (pelican B-17), acetic acid (Smart Lab, Indonesia), and $\mathrm{NaCl}$ (Otsuka, Indonesia). A spectrophotometer (Shimadzu, Japan) was also used in this study.

\section{Plant materials}

The rhizomes of $C$. mangga were collected from Medan, Sumatera Utara, Indonesia. Then, the plant was authenticated in Herbarium Medanense, Universitas Sumatera Utara, Indonesia.

\section{Extraction procedure}

The plant materials were allowed to dry under shade. $350 \mathrm{~g}$ of dried material of plant sample was ground and macerated in ethanol at the ratio of $1: 10(\mathrm{w} / \mathrm{v})$. The extraction was repeated twice on the residue. The filtrates were combined, and the solvent was removed 
under reduced pressure to obtain an extract of C. mangga (38.4 g, $10.95 \% \mathrm{w} / \mathrm{w})$.

\section{Phagocytosis response}

The phagocytosis ability was evaluated by carbon clearance method as described previously with slightly modification [20]. The animals were treated with ethanol extract of C. mangga at doses of 100, 200, and $400 \mathrm{mg} / \mathrm{kg}$ BW for 7 days. Meanwhile, the negative control group received $\mathrm{Na}$ CMC $0.5 \%$ as vehicle. Imboost ${ }^{\circledR}$ was used as positive control at a dose of $32.5 \mathrm{mg} / \mathrm{kg}$ BW. On day 8 , all the animals received the treatment of an intravenous injection of $(0.1 \mathrm{ml}$ per $10 \mathrm{~g})$ China ink dispersion via tail vein. Thereafter, $25 \mu \mathrm{L}$ of blood samples were collected from each animal at an interval of 5, 10, 15, and 20 minutes after the injection of ink dispersion. Blood samples were added to $4 \mathrm{ml}$ of $1 \%$ acetic acid to lyse the erythrocytes. Absorbance of the samples was measured at $640.5 \mathrm{~nm}$ using spectrophotometer. After $12 \mathrm{hrs}$ of blood, collection animals were sacrificed and the livers and spleens were collected and weighed.

Rate of carbon clearance (K), and phagocytic index $(\alpha)$ were calculated using following formula:

Rate of carbon clearance $(K)=\frac{\log \text { OD } 5-\log \text { OD20 }}{t 2-t 1}$

Phagocytic index $(\alpha)=\frac{\mathrm{K}^{1 / 3} \times \text { body wt of animal }}{\text { Liver wt }+ \text { spleen } w t}$

Where, OD5 is the log absorbance of blood at 5 minutes; OD20 is $\log$ absorbance of blood at 20 minutes; $t_{2}$ is the last time point of blood collection; $t_{1}$ is the first time point of blood collection. The use of mice was approved by the Animal Research Ethics Committees of Universitas Sumatera Utara (approval number 599/KEPH-FMIPA/2016).

\section{Total leukocyte count}

After the treatment with extracts for 7 days and injection with carbon ink dispersion, the blood sample of all animals was also collected for determination of total leukocyte count.

\section{Statistical analysis}

The data were analyzed using Statistical Package for Social Sciences (SPSS) version 15.0. Each sample was measured in triplicate and the data presented as mean \pm standard error of the mean. Data were analyzed using a one-way analysis of variance for multiple comparisons and followed by Tukey post hoc test. $\mathrm{p}<0.05$ was considered to be different significantly.

\section{RESULTS AND DISCUSSION}

\section{Phagocytosis response}

Phagocytosis is performed using pseudopodia which are extended to surround an organism or particle and followed by intracellular destruction [21]. The effect of ethanol extract on phagocytosis ability of mice leukocytes was determined by the removal of carbon from bloodstream. The enhanced clearance rate of carbon particle from blood flow indicates the increment of phagocytosis activity of leukocytes. The rate of carbon clearance of the C. mangga extract at different doses (100, 200 , and $400 \mathrm{mg} / \mathrm{kg}$ ) was higher than the negative control $(\mathrm{p}<0.05)$, signifying that they were increasing the percentage of carbon ingestion and thus stimulating the phagocytic cells (Table 1). The stimulation on carbon engulfment of $C$. mangga was in a dose-dependent manner. The ethanol extract of C. mangga at a dose of $400 \mathrm{mg} / \mathrm{kg} \mathrm{BW}$ demonstrated the strongest stimulant with phagocytic index of 6.71 which was comparable with those of positive control, Imboost ${ }^{\circledR}$ with phagocytic index of 6.82 (Fig. 1). Imboost ${ }^{\circledR}$ is a marketed drug to enhance an immune system which contained Echinacea purpurea $250 \mathrm{mg}$, black elderberry $400 \mathrm{mg}$, and zinc picolinate $10 \mathrm{mg}$. The previous study

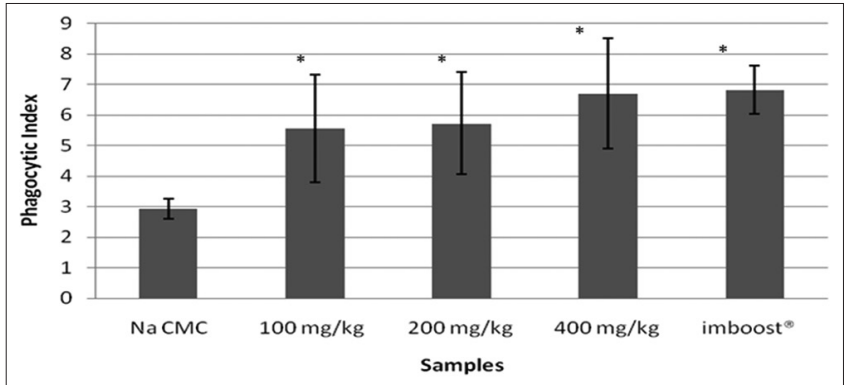

Fig. 1: Effect of administration of ethanol extract of Curcuma mangga rhizomes on phagocytic index. Data are mean \pm standard error of the mean $(n=5) ;{ }^{*} p<0.05$ compared to the respective control

Table 1: Effect of ethanol extract of $C$. mangga rhizomes on rate of carbon clearance

\begin{tabular}{lll}
\hline S.No. & Samples & Rate of carbon clearance \\
\hline 1 & Na CMC & $0.0059 \pm 0.0027$ \\
2 & $100 \mathrm{mg} / \mathrm{kg} \mathrm{BW}$ & $0.0283 \pm 0.0065^{*}$ \\
3 & $200 \mathrm{mg} / \mathrm{kg} \mathrm{BW}$ & $0.0301 \pm 0.0051^{*}$ \\
4 & $400 \mathrm{mg} / \mathrm{kg} \mathrm{BW}$ & $0.0411 \pm 0.0084^{*}$ \\
5 & Imboost $^{\circledR}$ & $0.0494 \pm 0.0167^{*}$ \\
\hline
\end{tabular}

Data were analyzed by one-way ANOVA, and followed by Tukey post hoc test. ${ }^{*} \mathrm{p}<0.05$ compared to the respective control, CMC: Carboxymethylcellulose, C. mangga: Curcuma mangga

Table 2: Effect of $C$. mangga extract on total leukocyte count (mean \pm SEM, $n=5$ )

\begin{tabular}{lll}
\hline S.No. & Samples & $\begin{array}{l}\text { Total leukocyte } \\
\text { count }\left(\mathbf{1 0}^{\mathbf{9}} / \mathbf{L}\right)\end{array}$ \\
\hline 1 & Na CMC & $6.24 \pm 0.73$ \\
2 & C. mangga extract $100 \mathrm{mg} / \mathrm{kg}$ & $8.26 \pm 0.66$ \\
3 & C. mangga extract $200 \mathrm{mg} / \mathrm{kg}$ & $8.03 \pm 0.87$ \\
4 & C. mangga extract $400 \mathrm{mg} / \mathrm{kg}_{5}$ & $7.85 \pm 0.71$ \\
5 & Imboost $^{\circledR}$ & $7.70 \pm 0.59$ \\
\hline
\end{tabular}

Data were analyzed by one-way ANOVA, and followed by Tukey post hoc test. None of the sample showed $\mathrm{p}<0.05$. C. mangga: Curcuma mangga, CMC: Carboxymethylcellulose

reported the ability of E. purpurea to stimulate cytokine release from macrophages [22].

The enhancement of phagocytosis activity to eradicate pathogens is markedly increase the immune system to protect the body from bacterial infection [23]. Fig. 1 shows that the phagocytic index of ethanol extract of $C$. mangga was more than those of negative control, indicating the immunostimulatory effect of $C$. mangga by enhancing phagocytosis ability. The result was in agreement with the previous study which reported the ability of methanol extract of $C$. mangga to enhance the phagocytosis response of human neutrophils by in vitro study [24].

\section{Total leukocyte count}

Cells of the immune system are generated from pluripotent hematopoietic stem cells in bone marrow. Thereafter, various immune cells are circulating in the blood stream, lymph, gastrointestinal system, and respiratory tract. The presence of pathogen-derived chemotactic factors attracts leukocytes to the site of infection [25]. Ethanol extract of $C$. mangga demonstrated low stimulation on the total leukocyte count as compared to negative control ( $p>0.05$ ) (Table 2). The previous study was also reported the inhibition effect of $C$. mangga on the migration of neutrophils to the site of infection [26]. 


\section{CONCLUSION}

The ethanol extract of $C$. mangga was able to modulate the innate immune response especially phagocytosis ability of mice phagocytes. In addition, the plant extracts revealed low stimulation on the total leukocyte count. The highest phagocytic index was observed when ethanol extract was administered at a dose of $400 \mathrm{mg} / \mathrm{kg}$. Hence, from the results obtained, it can be concluded that $C$. mangga has therapeutic potential and could be served as an effective immunomodulatory candidate. However, further studies are required to elucidate their activities on other mechanisms of immunomodulatory responses.

\section{ACKNOWLEDGMENT}

This work was supported by University of Sumatera Utara through BPPTN research grant scheme in 2016.

\section{REFERENCES}

1. Elgert KD. Immunology Understanding the Immune System. $2^{\text {nd }}$ ed. Virginia: A John Wiley \& Sons, Inc.; 2009.

2. Kobayashi SD, Voyich JM, Burlak C, DeLeo FR. Neutrophils in the innate immune response. Arch Immunol Ther Exp (Warsz) 2005;53(6):505-17.

3. Bogdan C. Nitric oxide and the immune response. Nat Immunol 2001;2:907-16.

4. Leiro J, Alvarez E, Arranz JA, Laguna R, Uriarte E, Orallo F. Effects of cis-resveratrol on inflammatory murine macrophages: Antioxidant activity and down-regulation of inflammatory genes. J Leukoc Biol 2004;75(6):1156-65.

5. Diwanay S, Chitre D, Patwardhan B. Immunoprotection by botanical drugs in cancer chemotherapy. J Ethnopharmacol 2004;90(1):49-55.

6. Gautam M, Diwanay S, Gairola S, Shinde Y, Patki P, Patwardhan B. Immunoadjuvant potential of Asparagus racemosus aqueous extract in experimental system. J Ethnopharmacol 2004;91(2-3):251-5.

7. Jayathirtha MG, Mishra SH. Preliminary immunomodulatory activities of methanol extracts of Eclipta alba and Centella asiatica. Phytomedicine 2004;11(4):361-5.

8. Yu L, Zhao M, Yang B, Bai W. Immunomodulatory and anti-cancer activities of phenolics from Garcinia mangostana fruit pericarp. Food Chem 2009;116(4):969-73. Available from: http://www.sciencedirect. com/science/article/pii/S0308814609003628.

9. Yuandani, Jantan I, Ilangkovan M, Husain K, Chan KM. Inhibitory effects of compounds from Phyllanthus amarus on nitric oxide production, lymphocyte proliferation, and cytokine release from phagocytes. Drug Des Devel Ther 2016;10:1935-45.

10. Nassara M, Zerizera S, Kabouchec Z, Kabouchec A, Bechkric S. Antioxidant and the immunomodulatory activities exhibited by three plants from Lamiaceae family. Int J Pharm Pharm Sci 2015;7(9):331-4. Available from: http://www.innovareacademics.in/journals/index.php/ ijpps/article/view/4618/2927.

11. Aichour R, Charef N, Baghiani A, Arrar L. Immunomodulatory effects of algerian caper. Int J Pharm Pharm Sci 2015;8(2):51-4. Available from: http://www.innovareacademics.in/journals/index.php/ijpps/ article/view/9779/3814.
12. Hong GW, Hong SL, Lee GS, Yaacob H, Malek SN. Non-aqueous extracts of Curcuma mangga rhizomes induced cell death in human colorectal adenocarcinoma cell line (HT29) via induction of apoptosis and cell cycle arrest at G0/G1 phase. Asian Pac J Trop Med 2016;9(1):8-18.

13. Malek SN, Lee GS, Hong SL, Yaacob H, Wahab NA, Faizal Weber JF, et al. Phytochemical and cytotoxic investigations of Curcuma mangga rhizomes. Molecules 2011;16(6):4539-48.

14. Abas F, Lajis NH, Shaari K, Israf DA, Stanslas J, Yusuf UK, et al. A labdane diterpene glucoside from the rhizomes of Curcuma mangga. J Nat Prod 2005;68(7):1090-3.

15. Ruangsang P, Tewtrakul S, Reanmongkol W. Evaluation of the analgesic and anti-inflammatory activities of Curcuma mangga Val and Zijp rhizomes. J Nat Med 2010;64(1):36-41.

16. Karsono AH, Tandrasasmita OM, Tjandrawinata RR. Molecular effects of bioactive fraction of Curcuma mangga (DLBS4847) as a downregulator of $5 \alpha$-reductase activity pathways in prostatic epithelial cells. Cancer Manage Res 2014;6:267-78. Available from: http://www. ncbi.nlm.nih.gov/pubmed/24944518.

17. Abas F, Lajis NH, Israf DA, Khozirah S, Kalsom YU. Antioxidant and nitric oxide inhibition activities of selected Malay traditional vegetables. Food Chem 2006;95:566-73. Available from: http://www. sciencedirect.com/science/article/pii/S0308814605001226.

18. Jantan I, Yassin MA, Chin CB, Chen LL, Sim NL. Anti-fungal activity of the essential oils of nine Zingiberaceae species. Pharm Biol 2003;41(5):392-7. Available from: http:/www.tandfonline.com/doi/ abs/10.1076/phbi.41.5.392.15941.

19. Yuandani, Suwarso E. Acute toxicity evaluation of ethanol extract of Curcuma mangga rhizome. Asian J Pharm Clin Res 2017;10(1):383-5. Available from: http://www.innovareacademics.in/journals/index.php/ ajpcr/article/download/16196/9671

20. Shukla S, Mehta A, John J, Mehta P, Vyas SP, Shukla S. Immunomodulatory activities of the ethanolic extract of Caesalpinia bonducella seeds. J Ethnopharmacol 2009;125(2):252-6.

21. Filias A, Theodorou GL, Mouzopoulou S, Varvarigou AA, Mantagos S, Karakantza M. Phagocytic ability of neutrophils and monocytes in neonates. BMC Pediatr 2011;11:29

22. Burger RA, Torres AR, Warren RP, Caldwell VD, Hughes BG. Echinacea-induced cytokine production by human macrophages. Int $\mathrm{J}$ Immunopharmacol 1997;19(7):371-9.

23. Greenberg S, Grinstein S. Phagocytosis and innate immunity. Curr Opin Immunol 2002;14(1):136-45.

24. Harun NH, Septama AW, Jantan I. Immunomodulatory effects of selected Malaysian plants on the CD18/11a expression and phagocytosis activities of leukocytes. Asian Pac J Trop Biomed 2015;5(1):48-53. Available from: http:/www.sciencedirect.com/science/article/pii/ S2221169115301702.

25. Skubixz KM, Hammerschmidt DE. Effects of ibuprofen on chemotactic peptide-receptor binding and granulocyte response. Biochem Pharmacol 2011;35:3349-54. Available from: http://www.sciencedirect. com/science/article/pii/000629528690434X.

26. Jantan I, Harun NH, Septama AW, Murad S, Mesaik MA. Inhibition of chemiluminescence and chemotactic activity of phagocytes in vitro by the extracts of selected medicinal plants. J Nat Med $2011 ; 65(2): 400-5$. 